\title{
Influence of Climatic Parameters on Soybean Subjected to Low Nitrogen Application Rates in Southern Guinea Savanna of Oyo State, Nigeria
}

\author{
Olukayode Stephen Oyatokun ${ }^{1 *}$, Kolapo Olatunji Oluwasemire ${ }^{2}$, Gideon Olajire Adeoye ${ }^{2}$ \\ ${ }^{1}$ Ajayi Crowther University, Oyo, Nigeria \\ ${ }^{2}$ University of Ibadan, Ibadan, Nigeria \\ Email: *os.oyatokun@acu.edu.ng
}

How to cite this paper: Oyatokun, O.S., Oluwasemire, K.O. and Adeoye, G.O. (2021) Influence of Climatic Parameters on Soybean Subjected to Low Nitrogen Application Rates in Southern Guinea Savanna of Oyo State, Nigeria. Agricultural Sciences, 12, 575-583.

https://doi.org/10.4236/as.2021.125037

Received: March 23, 2021

Accepted: May 21, 2021

Published: May 24, 2021

Copyright $\odot 2021$ by author(s) and Scientific Research Publishing Inc. This work is licensed under the Creative Commons Attribution International License (CC BY 4.0).

http://creativecommons.org/licenses/by/4.0/

\begin{abstract}
The variability in weather patterns consequent upon climate change constitutes a critical factor influencing soil $\mathrm{N}$ availability and the performance of crops. This paper aimed at evaluating the effects of climatic factors on soybean subjected to low $\mathrm{N}$ rates under rain-fed situation in the southern Guinea agro-ecology of Oyo State, Nigeria. A 2-year field experiment involving two soybean varieties (TGx1485-1D and TGx1448-2E) and five low rates of N fertilizer application $(0,5,15,25,35 \mathrm{~kg} / \mathrm{ha})$ using Urea applied by banding 7 days after planting was arranged in a $5 \times 2$ split-plot with three replications. $\mathrm{N}$ rates constitute the main plot while variety constitutes the sub-plot. Parameters measured include dry shoot weight, shoot $\mathrm{N}$ accumulation, and grain yield. Data were subjected to GENSTAT statistical package for analysis, and means separated with Duncan Multiple Range Test (DMRT) at 5\% level of probability. Climatic parameters of rainfall, temperature, and potential evapotranspiration data were collected from the surface observatory of the National meteorological agency (NIMET) and subjected to Excel package for computation and graphics. The dry shoot weight increases as $\mathrm{N}$ rate increases up to $25 \mathrm{~kg} / \mathrm{ha}$, but declines at $35 \mathrm{~kg} / \mathrm{ha}$ application rate, however, TGx14482E produced a higher dry shoot weight (2.9 t/ha) than TGx1485-1D (2.8 $\mathrm{t} / \mathrm{ha}$ ). Low $\mathrm{N}$ rates had no significant effects on shoot $\mathrm{N}$ accumulation and there was no significant difference in varietal response. Low $\mathrm{N}$ rate did not affect grain yield, but the TGx1448-2E had a greater yield of $1.5 \mathrm{t} / \mathrm{ha}$ than TGx1485-1D (1.30 t/ha). Annual rainfall amounts were $935.5 \mathrm{~mm}$ and1475.8 $\mathrm{mm}$ in 2009 and 2010 respectively. Potential evapotranspiration (PET) values were $1676.5 \mathrm{~mm}$ and $1676.8 \mathrm{~mm}$ in 2009 and 2010 respectively. Temperature values range from $24^{\circ} \mathrm{C}$ to $29.8^{\circ} \mathrm{C}$ in both years and the mean monthly temperature for 2009 was $26.5^{\circ} \mathrm{C}$ and $27.1^{\circ} \mathrm{C}$ for 2010 . The application of $\mathrm{N}$ ferti-
\end{abstract}


lizer to soybean requires appropriate timing for effective use. Climatic parameters such as rainfall, temperature, and evapotranspiration have dire consideration for fertilizer use and efficiency.

\section{Keywords}

Low N-Rate, Soybean Variety, Climatic Parameters, Dry Shoot Weight, Grain Yield

\section{Introduction}

Agricultural production in Nigeria and in the tropics is predominantly dependent on rainfall and other climatic factors. Therefore, the roles of rainfall, temperature, and evapotranspiration in agriculture are of paramount importance in agricultural production. While rainfall provides water for plants' metabolic activities and medium in which nutrient elements are dissolved and transported to various plant organs for growth and developmental processes; temperature provides the heat required by crop-plant to progress from one developmental stage to another. Evapotranspiration explains the demand for water by the environment and the balance between plant requirements and the environment. The timing, amount, and intensity of occurrence of these climatic indices have serious implications on the expression of productive potentials and eventual survival of crop plants. The variability in weather patterns consequent upon climate change constitutes a critical factor influencing soil $\mathrm{N}$ availability and the performance of crops.

The cultivation of legumes especially soybean is usually without the application of nitrogen fertilizer. This is because leguminous crops fix atmospheric nitrogen in conjunction with their symbiotic-bacteria in the soil for their use and that of the following or accompanying crops. A good number of studies had been conducted on leguminous species, where nitrogen fertilizer application was used. The outcome of such studies gave mixed results with either an increased yield or reduction in yield [1].

Gbonran $\left(8.1^{\circ} \mathrm{N} ; 3.5^{\circ} \mathrm{E} ; 379 \mathrm{~m} \cdot \mathrm{asl}\right)$ lies in the southern Guinea savanna agroecology in the northern part of Oyo state, usually regarded as the food basket of the state. The Agroecology is famous for soybean production, from where Nigeria-the highest producer of soybean in Africa, derived its status. The soils are derived from basement complex rock which is in an advanced weathering form and characterized by low cation exchange capacity [2]. The low capacity has marked consequences for fertilizer application and management of soil fertility, due to its poor ability to supply nutrients to the plant and/or retain nutrients. This inherently low fertility is compounded by intensive cultivation of the soil leading to annual yield decline. The soils of Gbonran are loamy sand with low fertility status, characteristic of the soils of sub-Saharan Africa, with low activity 
clay lattice structure, which has low nutrient and moisture retention abilities.

Application of nutrients to the soil, especially the application of fertilizer nitrogen, is therefore required to ameliorate leaching losses resulting from the high intensity of rainfall in this area. The sustenance of land productivity requires the availability of plant nutrients, the principal of which is nitrogen.

Soybean is a very versatile crop owing to its high protein contents and high quality edible oil [3]. The cultivation of soybean has had tremendous effects on the socio-economic and nutritional requirements of rural lives in Guinea savanna of Nigeria [4]. Various foods are processed from soybeans to improve the wellbeing of communities in the rural areas in Nigeria. This paper, therefore, aimed at evaluating the effects of climatic factors on soybean grown with low $\mathrm{N}$ rates under rain-fed situation at Gbonran, Oyo State of Nigeria with the objectives of determining the rainfall amount in the area and evaluating the effects on $\mathrm{N}$ application for soybean production in the study site.

\section{Materials and Methods}

\section{Study location}

Gbonran is an agrarian community in the northern part of Oyo state, which lies within the southern Guinea savanna of Nigeria. The location is famous with soybean production

\section{Soil Sampling and analysis}

Surface soil samples $(0-15 \mathrm{~cm})$ were randomly collected from 15 spots on the study field with a soil auger and bulked (mix thoroughly) to form a composite. The soil was air dried and passed through $2 \mathrm{~mm}$-sieve and a sub-sample was taken for pre-planting physical and chemical analysis.

\section{Planting Materials}

Soybean seeds were obtained from International Institute for Tropical Agriculture (IITA). The two varieties (TGx1485-1D and TGx1448-2E) are highly promiscuous varieties [5].

\section{Experimental procedures and design}

A 2-year field experiment involving two soybean varieties and five low rates of $\mathrm{N}$ fertilizer application using Urea $(46 \% \mathrm{~N})$ was carried out. The experiment was laid out as a $5 \times 2$ split-plot arrangement with treatments replicated three times in a randomized complete block design. The treatments are five (5) low $\mathrm{N}$ rates of 0 (control), 5, 15, 25 and $35 \mathrm{~kg} \cdot \mathrm{N} / \mathrm{ha}$ (main plot factors) and two (2) soybean varieties TGx1485-1D and TGx1448-2E (sub-plot factors).

Planting was done on June 28, 2009 and June 11, 2010 for the two years respectively. A total land area of $665 \mathrm{~m}^{2}$ was allocated for the field trial. The land was cleared, marked and pegged into $5 \mathrm{~m} \times 4.5 \mathrm{~m}\left(22.5 \mathrm{~m}^{2}\right)$ plots. Planting was done at a planting distance of $75 \mathrm{~cm} \times 5 \mathrm{~cm}, 1$ soybean seed/hole and $3-4 \mathrm{~cm}$ planting depth to give a total plant population of 266,667 plants per hectare. The fertilizer $\mathrm{N}$ was applied in the form of urea $(46 \% \mathrm{~N})$ by banding at 1 week after planting (WAP) while weeding was done by hoeing once before canopy estab- 
lishment.

\section{Measurements}

Parameters measured include dry shoot weight, shoot $\mathrm{N}$ accumulation and grain yield at harvest. These parameters were measured from the designated harvest area covering $1 \mathrm{~m} \times 1.5 \mathrm{~m}$ per treatment administered, where each plant is surrounded by other plants and not located along the bother-line. The plants were cut at the soil level. Pods on the main stem and branches were removed, the shoot weight (after removing the pods) was obtained by oven-drying at $80^{\circ} \mathrm{C}$ for 72 hours to a constant weight according to the procedures describes by [6] and weighed using an electronic weighing balance, MP $600 \mathrm{H}$. The shoot $\mathrm{N}$ content was determined by micro-Kjedahl method [7]. Grain yield was obtained at harvesting by weighing the grains obtained from the removed pods with an electronic weighting balance. All data were subjected to GENSTAT statistical package [8] for analysis, and means were separated with Duncan Multiple Range Test (DMRT) at $5 \%$ level of probability [9].

Data were also collected on the climatic factors of rainfall, temperature and potential evapotranspiration from the surface observatory of National Meteorological Agency (NIMET) Zonal Office, Iseyin, about ten (10) km from the studysite.

Meteorological data collected were subjected to Excel package for computation and graphics.

\section{Results}

The physical and chemical properties of the soil are presented in Table 1. The $\mathrm{pH}$ of the soil is 6.4. The total $\mathrm{N}$, available $\mathrm{P}$ and organic $\mathrm{C}$ of the soil were low. The top soil is loamy sand, having over $80 \%$ sand component in texture. The total monthly rainfall, evapotranspiration and average monthly temperatures for year 2009 and 2010 are presented in Table 2. Annual rainfall amounts were $935.5 \mathrm{~mm}$ and1475.8 $\mathrm{mm}$ in 2009 and 2010 respectively. Potential evapotranspiration (PET) values were $1676.5 \mathrm{~mm}$ and $1676.8 \mathrm{~mm}$ in 2009 and 2010 respectively. Temperature values range from $24^{\circ} \mathrm{C}$ to $29.8^{\circ} \mathrm{C}$ in both years and the mean monthly temperature for 2009 was $26.5^{\circ} \mathrm{C}$ and $27.1^{\circ} \mathrm{C}$ for 2010 . Figure 1 and Figure 2 present the relationship between environmental demand for water (evapotranspiration) and the decadal/monthly rainfall distribution in 2009 and 2010 cropping seasons. The effects of $\mathrm{N}$ rates and variety on yield and yield parameters are presented in Table 3 . Low $\mathrm{N}$ rates had no significant effects on shoot $\mathrm{N}$ accumulation in soybean and there was no significant difference in varietal response. The dry shoot weight increases as $\mathrm{N}$ rate increases up to $25 \mathrm{~kg} / \mathrm{ha}$, but declines at $35 \mathrm{~kg} / \mathrm{ha}$ application rate, however, TGx14482E produced a higher dry shoot weight (2.9 t/ha) than TGx1485-1D (2.8 t/ha). The grain yields occasioned by the $\mathrm{N}$ rate were not statistically different, but the variety TGx1448-2E had a greater yield of $1.5 \mathrm{t} /$ ha than TGx1485-1D (1.3 t/ha). 


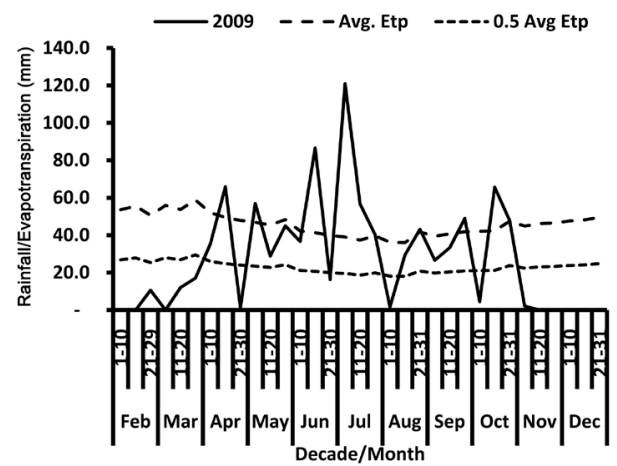

Figure 1. Relationship between environmental demand for water (Evapotranspiration) and decadal rainfall distribution during the 2009 rainy season at Iseyin.

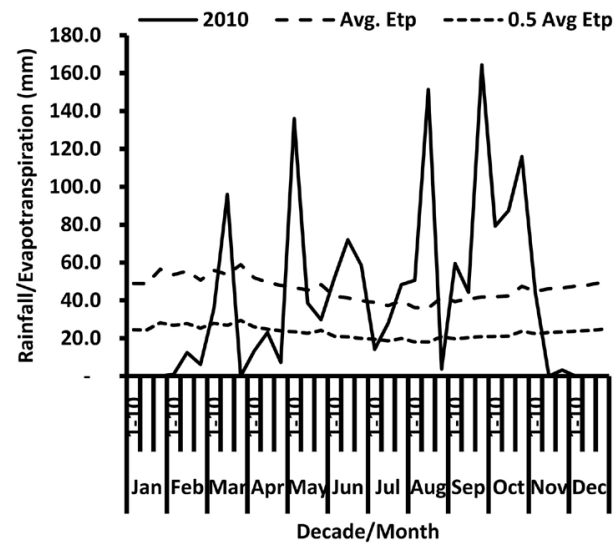

Figure 2. Relationship between environmental demand for water (Evapotranspiration) and decadal rainfall distribution during the 2010 rainy season at Iseyin.

Table 1. Physical and chemical properties of soil at Gbonran experimental site.

\begin{tabular}{cc}
\hline Parameters & Gbonran \\
\hline $\mathrm{pH}\left(\mathrm{H}_{2} \mathrm{O}\right)$ & 6.4 \\
Total Nitrogen $(\mathrm{g} / \mathrm{kg})$ & 1.0 \\
Organic Carbon $(\mathrm{g} / \mathrm{kg})$ & 12.1 \\
Avail. P $(\mathrm{mg} / \mathrm{kg})$ & 7.3 \\
Exchangeable cations $(\mathrm{cmoles} / \mathrm{kg})$ & 1.9 \\
$\mathrm{Ca}$ & 1.2 \\
$\mathrm{Mg}$ & 0.2 \\
$\mathrm{~K}$ & 0.3 \\
$\mathrm{Na}$ & 0.3 \\
Exchangeable Acidity & 68 \\
Particle size analysis $(\mathrm{g} / \mathrm{kg})$ & 120 \\
Clay & 812 \\
Silt & Loamy Sand \\
Sand &
\end{tabular}


Table 2. Total monthly rainfall, potential evapotranspiration and mean monthly temperature for 2009 and 2010.

\begin{tabular}{|c|c|c|c|c|c|c|}
\hline \multirow[t]{2}{*}{ Month } & \multicolumn{2}{|c|}{ Rainfall (mm) } & \multicolumn{2}{|c|}{$\begin{array}{c}\text { Potential } \\
\text { Evapotranspiration }(\mathrm{mm})\end{array}$} & \multicolumn{2}{|c|}{$\begin{array}{c}\text { Mean Monthly } \\
\text { Temperature }\left({ }^{\circ} \mathrm{C}\right)\end{array}$} \\
\hline & 2009 & 2010 & 2009 & 2010 & 2009 & 2010 \\
\hline Jan & 2.1 & 0.0 & 170.2 & 170.2 & 27.8 & 28.7 \\
\hline Feb & 10.6 & 19.5 & 174.0 & 168.2 & 28.1 & 29.8 \\
\hline Mar & 29.0 & 131.6 & 169.4 & 169.9 & 29.5 & 29.1 \\
\hline Apr & 102.4 & 43.5 & 149.0 & 149.8 & 27.0 & 28.9 \\
\hline May & 130.7 & 204.4 & 127.4 & 128.2 & 26.9 & 27.1 \\
\hline Jun & 139.5 & 167.4 & 115.1 & 115.3 & 25.7 & 26.7 \\
\hline Jul & 217.9 & 105.3 & 108.5 & 108.5 & 24.8 & 24.9 \\
\hline Aug & 74.5 & 205.7 & 111.5 & 110.9 & 24.0 & 24.8 \\
\hline Sep & 108.9 & 256.5 & 121.5 & 120.8 & 24.5 & 25.4 \\
\hline Oct & 117.8 & 240.5 & 136.2 & 136.5 & 25.8 & 25.9 \\
\hline Nov & 2.1 & 101.4 & 138.5 & 138.5 & 26.1 & 26.8 \\
\hline Dec & 0.0 & 0.0 & 155.2 & 160.0 & 27.3 & 27.1 \\
\hline Total/Mean & 935.5 & 1475.8 & 1676.5 & 1676.8 & 26.5 & 27.1 \\
\hline
\end{tabular}

Source: NIMET Zonal Office, Iseyin.

Table 3. Effects of low $\mathrm{N}$ rate and variety on yield and yield parameters in Gbonran (2009-2010).

\begin{tabular}{cccc}
\hline Treatment & \% Shoot N & Dry shoot weight (t/ha) & Grain yield (t/ha) \\
\hline 0 & 2.91 & 2.40 & 1.09 \\
5 & 2.56 & 2.60 & 1.07 \\
15 & 2.89 & 2.92 & 1.08 \\
25 & 2.33 & 3.10 & 1.09 \\
35 & 2.78 & 3.06 & 1.07 \\
LSD (0.05) & $0.94 \mathrm{~ns}$ & $1.64 \mathrm{~ns}$ & $0.19 \mathrm{~ns}$ \\
& & Soybean variety & 1.35 \\
TGx1485-1D & 2.81 & 2.80 & 1.54 \\
TGx1448-2E & 2.57 & 2.90 & 0.13 \\
LSD (0.05) & $0.43 \mathrm{~ns}$ & 0.93 & \\
\hline
\end{tabular}

ns-not significant.

\section{Discussion}

The textural property of the soil makes the soil porous and hence devoid of colloidal materials or surfaces on which plant nutrients can adhere to (i.e. low nu- 
trient retention capacity). It also has serious implications on the water retention capacity of the soil and consequently affects the ultimate performance of soybean.

The meteorological data implied that moisture deficits of $741 \mathrm{~mm}$ and 219 mm were recorded in 2009 and 2010 respectively. These deficits were however encountered for five months (November, December, January, February, and March) in 2009, which are regarded as the dry season in the region. It revealed that the planting season started around May and it stabilized in June. The monthly average temperature in the study period was within the $22^{\circ} \mathrm{C}-30^{\circ} \mathrm{C}$ which is the recommended optimum temperature range for soybean production [10]. Moreover, the daily distribution of precipitation displayed in Figure 1 and Figure 2 showed high concentration of rain in the month of June which is the planting month.

The meteorological data of the area also indicated that the area experienced heavy rains early in 2009 and 2010 cropping seasons. The rainy season in 2009 started in April and ended October; hence there were five months of dry season (November-March). The planting of soybean by June 28, 2009 coincided with a period of heavy downpour. The rainfall amount peaked in July, during which time fertilizer application was made. At this period, rainfall amount far exceeded the demand of the environment for water (potential evapotranspiration), leaving the soil saturated with moisture, thus making the fertilizer amenable to quick dissolution and leaching/runoff losses because of intense rain events. During the 2010 cropping season, however, the rain started earlier and was with greater amount and intensity. There were ten months of rain and two dry months (December and January). The cropping season also witnessed a heavy downpour with a short spell towards August ending which was not long enough to give soybean moisture stress. As a result of rainfall amount and intensity, fertilizer applied seven days after planting was not effectively utilized because the soils were saturated with moisture, thereby predisposing the fertilizer material (urea) which is water-soluble, to leaching and erosion losses.

The response of soybean to low $\mathrm{N}$ rate was similar in terms of dry shoot weight, however, varietal response varied, where variety TGx1485-1D had a lesser dry shoot weight than variety TGx1448-2E. The response in terms of shoot $\mathrm{N}$ accumulation was similar for both low $\mathrm{N}$ application rate and variety. The finding revealed that low nitrogen rate has no effect on the performance of soybean in the study area. This corroborated previous works by [11] [12] whose reports have indicated that in most cases, soybean grown on most soils does not respond to low rates of nitrogen fertilizers. The response of soybean in terms of grain yield varied both for $\mathrm{N}$ rate and variety, such that TGx1448-2E outperformed TGx1485-1D. The variation observed in varietal response might be an indication that TGx1448 possesses a better genetic vigor for biomass accumulation and grain yield than TGx1485-1D. This is in agreement with earlier works by [13] [14] who observed significant differences among soybean cultivars. 


\section{Conclusion}

Application of $\mathrm{N}$ fertilizer to soybean requires appropriate timing for effective use. Climatic parameters such as rainfall, temperature, and evapotranspiration have dire consideration for fertilizer use and efficiency.

\section{Conflicts of Interest}

The authors declare no conflicts of interest regarding the publication of this paper.

\section{References}

[1] Salvagiotti, F., Cassman, K., Specht, J., Walters, D., Weiss, A. and Dobermann, A. (2008) Nitrogen Uptake, Fixation and Response to Fertilizer N in Soyabeans: A Review. Field Crops Research, 108, 1-13. https://doi.org/10.1016/j.fcr.2008.03.001

[2] Gbadegesin, A. and Akinbola, G.E. (1995) Reference Soils of the Southern Guinea Savanna Region of Central-Western Nigeria (Oyo State). Soil Brief Nigeria 7. Unversity of Ibadan and ISRIC, Wageningen, $15 \mathrm{p}$.

[3] Akande, S.R, Owolade, O.F. and Ayanwole, J.A. (2007) Field Evaluation of Soyabean Varieties at Ilorin in the Southern Guinea Savanna Ecology of Nigeria. African Journal of Agricultural Research, 2, 356-359.

[4] Sanginga, P.C., Adesina, A.A., Manyong, U.M., Otite, O. and Dashiell, K.E. (1999) Social Impact of Soyabean in Nigeria's Southern Guinea Savanna. IITA, Ibadan, Nigeria, $32 \mathrm{p}$.

[5] International Institute of Tropical Agriculture (IITA) (1993) Crop Improvement Division: Grain Legume Improvement Programme Part III Soyabean: Archival Report (1988-1992). IITA, Ibadan, Nigeria. 10 p.

[6] International Institute of Tropical Agriculture. (1982) Selected Methods for Soil and Plant Analysis: IITA Manual Series 7. International Institute of Tropical Agriculture, Ibadan Nigeria.

[7] Bremmer, J.M. and Mulvaney, C.S. (1982) Nitrogen-Total. In: Page, A.L., Ed., Methods of Soil Analysis. Part 2 Chemical and Microbiological Properties, American Society of Agronomy, Soil Science Society of America, Madison, Wisconsin, 595624. https://doi.org/10.2134/agronmonogr9.2.2ed.c31

[8] Genstat. (1995) Genstat 5 Release 3.2 for Windows 95. Lawes Agricultural Trust, Rothamstead Experimental Station, UK, 147 p.

[9] Steel, R.G.D. and Torrie, J.H. (1987) Principles and Procedures of Statistics: A Biometrical Approach. 2nd Edition, McGrawHill Book Company, London, UK, 102 p.

[10] Phillipine Council for Agriculture and Resource Research and Development (PCARRD)/ United State Department of Agriculture (USDA). (1986) Environmental Adaptation of Crops. PCARRD Books Series No. 37, Los Banos, Laguna, Phillipines.

[11] Heatherly, L.G., Spurlock, S.R. and Reddy, K.N. (2003) Influence of Early-Season Nitrogen and Weed Management on Irrigated and Non-Irrigated GlyphosateResistant and Susceptible Soybean. Agronomy Journal, 95, 446-453. https://doi.org/10.2134/agronj2003.4460

[12] Hoeft, R.G., Nafziger, E.D., Johnson, R.R. and Aldrich, S.R. (2000) Modern Corn and Soybean Production. 1st Edition, Modern Corn and Soybean Production (MCSP) Publications, Champaign, IL, 353 p. 
[13] Okpara D.A. and Ibiam, B. (2000) Evaluation of Soyabean Varieties for Adaptability to a Humid Tropical Environment in South-East Nigeria. Journal of Sustainable Agriculture and Environment, 2, 26-31.

[14] Yusuf, L.A. and Idowu, A.A. (2000) Evaluation of Four Soyabean Varieties for Performance under Different Lime Regimes on the Acid Soil of Uyo. Tropical Oilseed Journal, 6, 65-70. 